\title{
HOLOGRAPHIC INTERFEROMETRY AS A METHOD FOR MEASURING STRAIN CAUSED BY POLYMERIZATION SHRINKAGE OF DENTAL COMPOSITE
}

\author{
T. Puškar ${ }^{1, *}$, D. Jevremović ${ }^{2}$, L. Blažić ${ }^{1}$, D. Vasiljevićc ${ }^{3}$, D. Pantelić ${ }^{3}$, \\ B. Murić ${ }^{3}$, B. Trifković ${ }^{4}$ \\ ${ }^{1}$ University of Novi Sad, Medical faculty, School of Dentistry, \\ Dental clinic of Vojvodina, Hajduk Veljkova 12, Serbia \\ ${ }^{2}$ University "Business academy", School of Dentistry, Pančevo, Department \\ of Prosthetic Dentistry, Zrenjaninski put 179, Pančevo, Serbia \\ ${ }^{3}$ University of Belgrade, Institute of Physics, Laboratory for optics and lasers, \\ Pregrevica 118, Zemun, Serbia \\ ${ }^{4}$ University of Belgrade, School of Dentistry, Clinic for Prosthodontics, \\ Belgrade, Rankeova 4, Serbia
}

\begin{abstract}
Polymerization shrinkage is one of the most critical properties of esthetic resin-based dental restorative materials and may have a negative impact on their clinical performance. As the composite is adhesively bonded, contraction of composite material that occurs during the polymerization causes stress and strain of hard dental tissues. Polymerization shrinkage also affects the maintenance of the bonded interface between the composite resin and dental hard tissues. The aim of this study is to present holographic interferometry as a method for detecting and measuring strain of dental hard tissue caused by the polymerization shrinkage of the dental composite. Materials and methods: Strain was measured experimentally, by real time holographic interferometry, on the maxillary teeth. Strain of dental tissue was determined by counting the interferomentic fringes that appeared during the polymerization process. Results: The deformation was recorded on the coronal dental tissue from $2.25 \mu \mathrm{m}$ to $5.8 \mu \mathrm{m}$. The conclusion is that holographic interferometry is a non-contact, non-destructive, very precise method for measuring deformation of hard dental tissues that is caused by the polymerization shrinkage of dental composite. ferometry.

Keywords: Resin based composites, polymerization shrinkage, holographic inter-
\end{abstract}

\section{INTRODUCTION}

In the last four decades, adhesive dentistry has remarkably evolved, greatly due to the development of BisGMA- based composites in the late 1950s. The incorporation of new monomers (UEDMA, BisEMA), new initiation systems and filler technologies have significantly improved the physical properties of composite materials having expanded their use as direct and indirect restoratives [1]. Their good mechanical properties, modulus of elasticity that is similar to dentin modulus, the fact that they could be strongly bonded to the sound dental tissue and good transmission of loading and stresses in function, made the resin composites very frequently used material in the restorative dentistry [2]. Also, they have very good esthetical characteristics. Their color and appearance is tooth like. Resin composites do not darken translucent, all-ceramic restorations thus they are the material of choice when preparing the abutment for all ceramic restorations as a core material, as the material for the dental post or as a composite cement [2]. One of the undesired characteristics of resin composites is polymerization shrinkage.

Polymerization process of dental composites is accompanied by a volumetric contraction, which results in the development of internal stress [3]. The stresses are a product of the non-yielding, or rigid nature of the reinforced cross-linked polymer network formed in the reaction. The stresses have been implicated in the imperfect margins formed around composite restorations, which may lead to a reduced restoration life [3]. In the course of the polymerization of resin composite, covalent bonds are created 
and molecular distances and free volume are reduced [3]. Several factors contribute to the production of the stresses in resin composite during the curing. During the polymerization, the shrinkage occurs simultaneously with the material acquiring rigidity, as the polymer chains lengthen and cross link amongst themselves or with neighboring chains. Polymerization stress and strain is influenced by the elastic modulus of the composite, by the flow capacity of the composite at early stages of the curing reaction (viscoelastic behavior) and by the level of confinement imposed on the material, which is estimated as the percentage of composite surface that is bonded to the dental tissue in relation to the total surface area.

Numerous methods have been proposed for measuring or estimating stress in the dental composites during polymerization contraction. The most common method was the use of force transducer uniaxial from a composite disk or a cylinder $[4,5,6$, $7]$, then photoelastic method $[8,9,10]$ and finite element analysis $[11,12]$.

Holographic interferometry, a non-destructive full-field technique that measures small static or dynamic deformations occurring in an object, is based upon standard holographic principles [13]. Holography was previously used to investigate various deformations of dentures or dental implants $[14,15]$. Holography is a method for recording three-dimensional information on a two-dimensional recording medium (photographic emulsion, thermoplastics, etc.) [16]. Unlike a photograph, the hologram contains all the information about the surface of the object and the effects of parallax [17]. The hologram is an interference pattern of coherent wave fronts scattered from the object and recorded by the medium [16]. The basic principles of holography underly the technique in double-exposure holographic interferometry [16]. Real-time holography is a dynamic method through which the deformations can be monitored during the entire experiment [17]. Detection and recording of the interference pattern can be done with CCD camera and computer [17].

The aim of this study is to promote the new methodology for detection and measurement analysis of strain and stress generation, in the course of preparation of the abutment tooth with resin composite core build up. Investigation is a combination of the experimental method and computational analyses.

\section{MATERIALS AND METHODS}

In the Figure 1, it is shown a holographic setup for real time holography. Highly coherent, 532 $\mathrm{nm}$ wavelength laser was used in the experiment.
Laser beam was split in order to produce reference and object wave-fronts. Object beam illuminated a tooth under investigation, while the reference beam illuminated a holographic plate (silver halide emulsion, manufactured by "Slavich", Russia). Reference-to-object beam intensity was adjusted by variable filter, enabling high diffraction efficiency of a final hologram. A plate was positioned in a liquid gate (container with glass walls), so that chemical processing could be done without moving the hologram. Composite polymerization was initiated by specially designed blue LED lamp (with spectrum centered at $480 \mathrm{~nm})$.

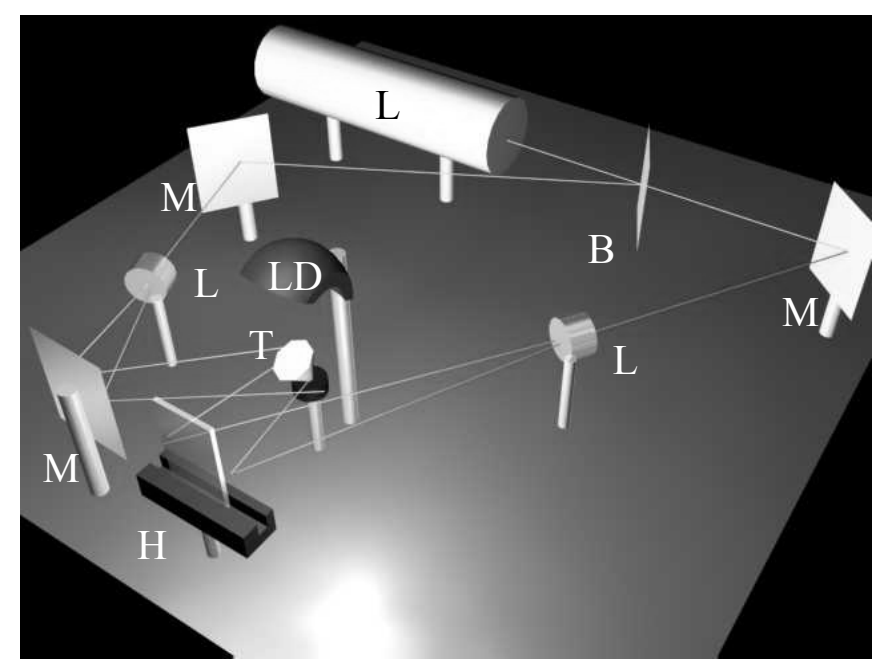

Figure 1. Real time holographic setup: L - laser, BS beam splitter, C - CCD camera, PC computer, LE - LED lamp, $L G$ - liquid gate for real time hologram processing, $T$ - tooth, $V$-variable attenuator, $M$ - mirror, $L S$ - lens, IF- $532 \mathrm{~nm}$ interference filter.

Experimental LED source was used to cure the composite. It had 42 LEDs that produced $2 \mathrm{~cm}$ diameter spot with $80 \mathrm{~mW} / \mathrm{cm}^{2}$ irradiance. Construction was hemispherical [17]. The lamp is placed directly above the tooth so that composite polymerization can be performed without contacting a tooth and with appropriate energy density, which should be 12 - $24 \mathrm{~J} / \mathrm{cm}^{2}$ [18]. Exposure time was $200 \mathrm{~s}$ and consequently, energy density was $16 \mathrm{~J} / \mathrm{cm}^{2}$ - quite suitable for successful polymerization. A CCD camera with $532 \mathrm{~nm}$ interference filter was used to record the interference pattern.

Intact maxillary second premolar, extracted for periodontal reasons, was selected for the study. The ethics board of the Dental clinic approved the research. The tooth was examined under a magnifier to ensure the absence of carious lesions, cracks and micro fractures. The tooth was stored in distilled water and $0.2 \%$ thymol solution at $37^{\circ} \mathrm{C}$. The standard endodontic procedure included canal preparation and 
opturation. The tooth was prepared with water-cooled diamond and carbide burs for the all-ceramic restoration, as a standard procedure [19]. A one millimeter wide rounded shoulder margin was formed one millimeter coronally from the cemento-enamel junction [19]. Subsequently the coronal cavity was prepared, so that the two coronal walls were preserved. Tooth was prepared with a ferule of $2 \mathrm{~mm}$ height and fixed with dental gypsum to an appropriate aluminum holder. After a short period of drying, a good mechanical contact between tooth and gypsum was obtained, enabling the stability during holographic measurements. The cavities were treated with self etched adhesive system AdheSE (Ivoclar Vivadent AG Fl-9494 Schaan/Liechtenstein) according to the manufacturers instructions, light cured, filled with composite core buid up (Tetric Evo Ceram, Ivoclar Vivadent AG Fl-9494 Schaan/Liechtenstein) and placed in the holographic setup.

The tooth had to be painted with silver paint. Otherwise, interference fringes would be barely visible [17]. The tooth was placed in the holographic setup, and a photosensitive plate was inserted into the liquid gate. The plate was soaked for several minutes (letting emulsion to swell). Consequently, it was exposed and developed in a fine grain developer. The resulting hologram was washed and left in water.

\section{RESULTS}

Dental composite was illuminated continuously for 200 seconds and pictures of holographic interferograms were recorded. The photograph of the interference pattern seen on the abuttment surface at the end of illumination is shown at the Figure 3.

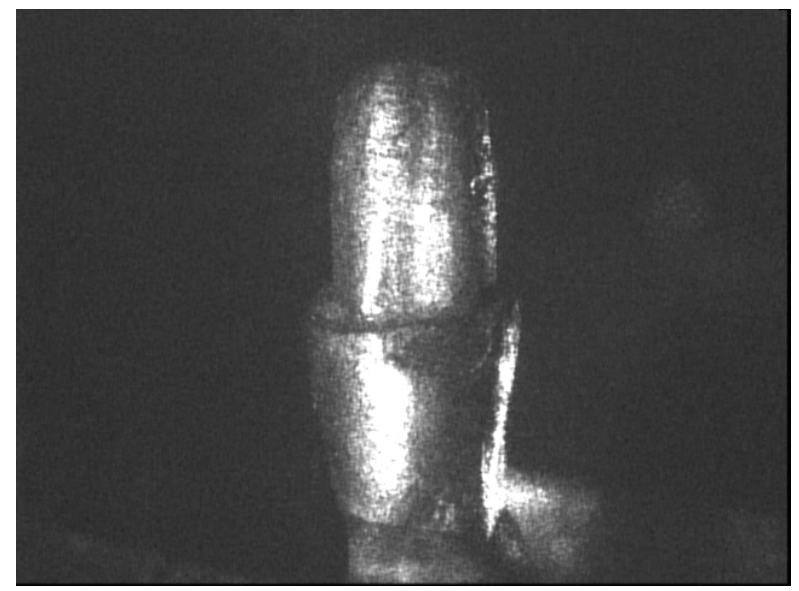

Figure 2. Photograph of the abutment before the polymerization of the core with two remaining cavity walls.

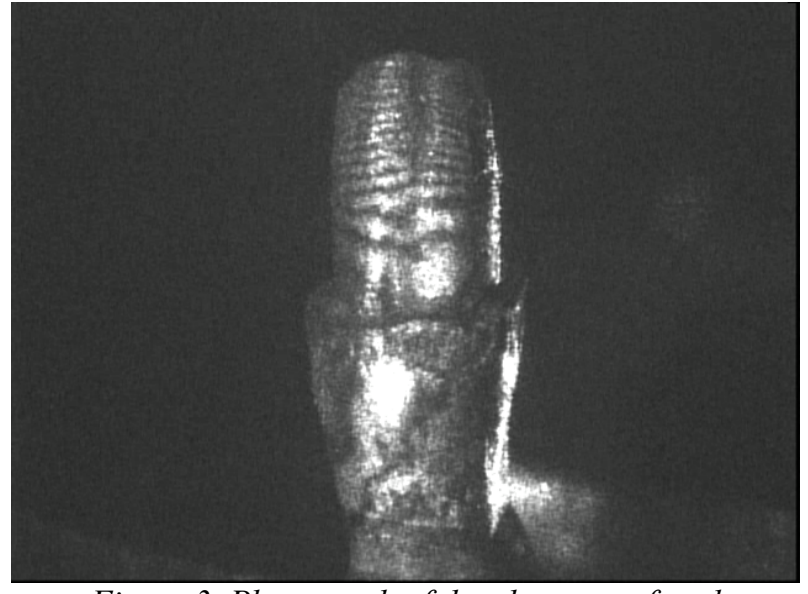

Figure 3. Photograph of the abutment after the polymerization of the core with two remaining cavity walls.

The first fringe appeared at the top of the abutment tooth and started traveling down, towards the root. Other fringes followed with increasing speed up to the moment when the process began to slow down.

The tooth interferogram was analyzed by counting fringes that appeared during illumination. The maximum deformation during our recording was attained at the end of the illumination process (after 200 s). When the tooth was restored with composite core build up restoration, 11 fringes appeared. One fringe is equivalent to approximately $532 \mathrm{~nm}$ deformation. That means that the deformation was $5.8 \mu \mathrm{m}$.

Numerical calculation of internal stress was performed, based on holographic deformation measurement. Mechanical model for the abutment with the prepared cavity was done according to the literature data describing the size and morphological characteristics of teeth. The model was made as a solid model with complex geometry in the program for solid modeling SolidWorks (Solid Works Corporation, USA) (Figure 4.). Geometry of the model is made according to the geometry of the abutment $t$ eeth, prepared for the all-ceramic crown [19]. Characteristics of the model are given in Table 1.

Table 1. Number of edges, solid faces and vertices on the model of the abutment with cavity.

\begin{tabular}{|c|c|}
\hline & Model 1 \\
\hline Solid faces & 30 \\
\hline Edges & 80 \\
\hline Vertices & 54 \\
\hline
\end{tabular}




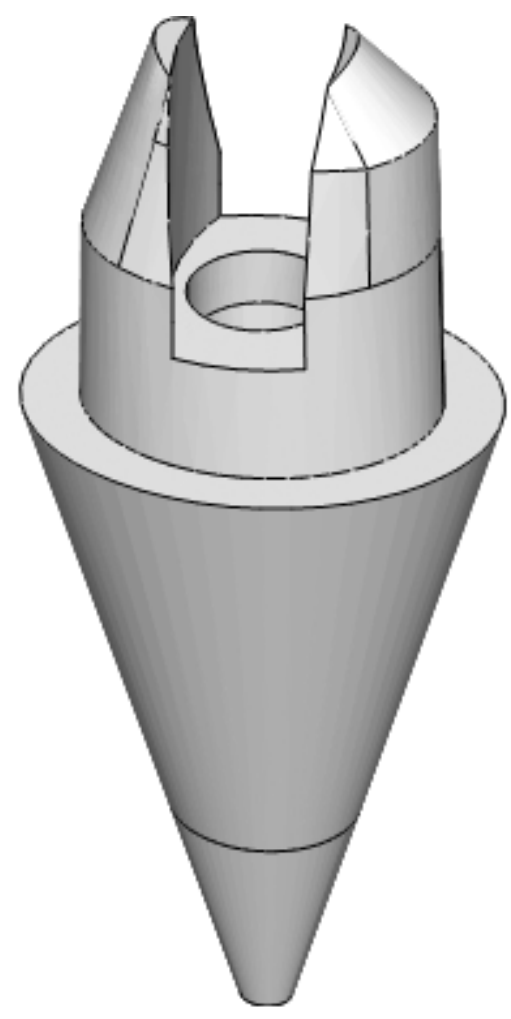

Model 1

Figure 4. Mechanical model of the abutment teeth with cavity.

The desired cavity has been formed, then the Solid model was transfered into the program for Finite Element Analysis (FEA) Abaqus (SIMULIA, Dissault Systems S.A., USA) and meshed with linear tetrahedral elements (Figure 5). Number of nodes and elements are given in Table 2.

Table 2. Number of nodes and elements of the meshed model.

\begin{tabular}{|c|c|}
\hline & Model 2 \\
\hline Number of nodes & 144101 \\
\hline Number of elements & 29176 \\
\hline
\end{tabular}

The mechanical properties (Young's modulus of elasticity and Poisson's ratio) for materials used in building the mechanical model and FE analysis are given in the Table 3 .

Table 3. Mechanical properties of dental tissue and used dental materials

\begin{tabular}{|c|c|c|}
\hline Materials & $\begin{array}{c}\text { Young's } \\
\text { modulus of } \\
\text { elasticity (MPa) }\end{array}$ & Poisson's ratio \\
\hline Dentin & 18600 & 0,31 \\
\hline $\begin{array}{c}\text { Tetric Evo } \\
\text { ceram }\end{array}$ & 17000 & 0,28 \\
\hline
\end{tabular}

${ }^{*}$ Data from the manufacturer (Ivoklar-Vivadent, Liechtenstein)

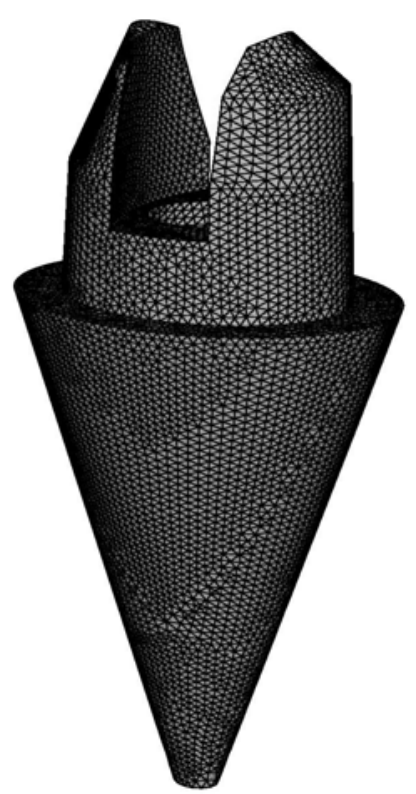

Model 2

Figure 5. Meshed model of the abutment.

It was assumed that the contraction forces exerted uniform pressure on cavity sides. Dental tissues were modeled as linear and isotropic. It was posible to calculate the internal stress at any stage of the composite contraction. First, the deformation was determined from the holographic interferogram, by taking into account experimental geometry (deformation direction is almost collinear with the line of sight, while the object beam deviates 45 degrees from the line of sight). Based on the deformation measurement, the internal stress was calculated [17].

Experimentally measured deformations are presented on the mathematical model (Figure 6.)

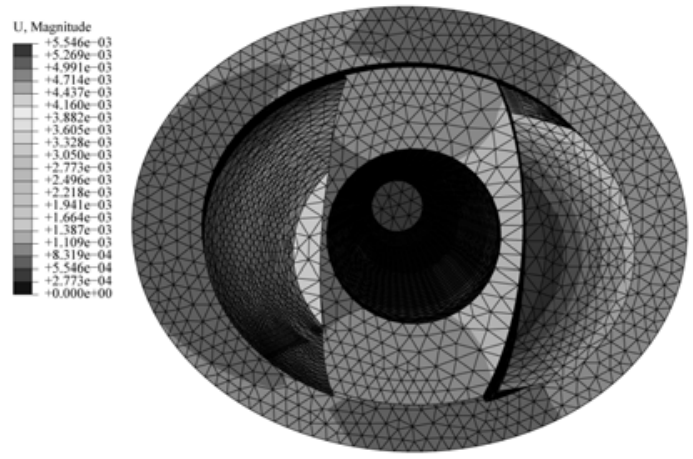

Figure 6. Experimentally measured deformations presented on the mathematical model.

The stress was calculated by using Abacus. It is presented as Von Mises stress (Figure 7.). 


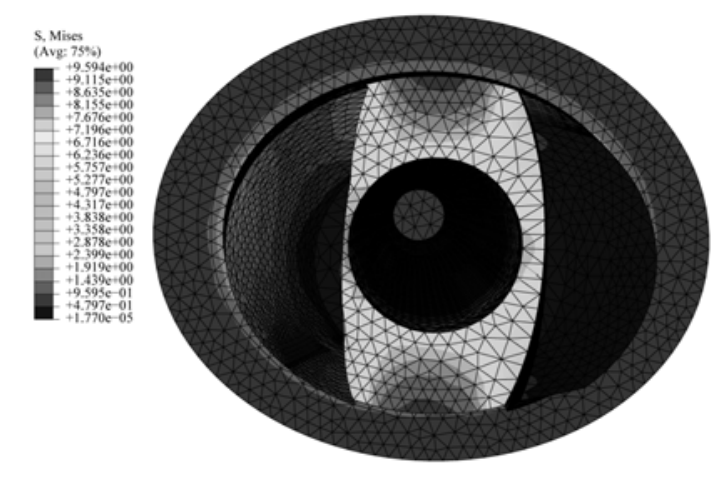

Figure 7. Calculated Von Mises stress

\section{DISCUSSION}

The roots of holography lie in the work of Wolfke and Braga and then Gabor, having promoted the idea of improving the resolution in the electron microscopy, by recording the reflected field of the object that is illuminated with electron beam. Practically, the introduction of lasers in holography, in 1962, enabled the introduction of holography as a methodology in the scientific work. 1971. Gabor received the Nobel price for his inventions, almost half a century after his first experiments.

A hologram is a photographic emulsion in which information about a scene is recorded in a special way. When the hologram is properly illuminated, the viewer sees a realistic 3D representation of the scene. Unique characteristic of holography is that optical information about the object is recorded (intensity, frequency, wave length and amplitude).

Laser produce highly coherent beam that is only a few millimeters in diameter. It is divergent through the divergent lens, so it could illuminate the object. Laser beam should be split, so one beam illuminates the object and reflects on the holographic plate and the other illuminates the object after reflection from the series of mirrors. When the two wave fronts are in interference, there are light and dark strips on the object, which are known as interferometric fringes.

Unlike methods with strain gauge $[4,5,6,7]$ that can measure strain only in one point of the investigated object, holographic interferometry enables recording and measurement of deformation of the whole investigated object. It is very accurate method. Precision is half of the wavelength of the laser beam that is used in the experiment (nanometer scale). In the presented investigation, $532 \mathrm{~nm}$ wavelength Nd Yag laser was used.

Also, if real time holographic interferometry is used, the deformation could be noticed, measured and recorded during the whole investigated period in every part of the object. Holography is a nondestructive methodology, so it does not include problems connected with the destruction of a specimen.

Photoelastic investigations $[8,9,10]$ have limitations because of inevitable usage of transparent materials. FEA [11, 12] has limitations that lie in simplifications of models and existing boundary conditions that must be made. Polymerization shrinkage of resin based dental composites is influenced by numerous factors, so it is very difficult to simulate the whole process by computational analyses.

Holographic interferometry, as an experimental method, takes into account all real factors that exist in the experiment and enables detecting and measuring of the real strain. Due to the above stated, holographic interferometry is superior to all mentioned methodologies for detecting and measuring strain. In combination with FEA gives great opportunities for analysis of stress distribution.

According to the present knowledge [20, 21] measured strain and calculated stress that appeare during the polymerization of the composite core build up could not cause damage to the hard dental tissue. Maximum Von Misses stress was $8 \mathrm{MPa}$, which represents the value many times smaller than the lowest value found in the literature that could cause damage of the dental tissue [20,21].

Combination of experimentally measured strain and computationally calculated stress gives the most realistic information of stress distribution in the dental tissue caused by the polymerization shrinkage of the dental composite.

\section{CONCLUSION}

Holographic interferometry is a non-contact, non-destructive, very precise method for measuring deformation of hard dental tissues that is caused by the polymerization shrinkage of dental composite.

\section{REFERENCE}

[1] R.R. Braga, R.Y. Ballester, J.L. Ferracane. Factors involved in the devolpment of polymerization shrinkage stress in resin-composites: A systemic review. Dent Mater, Vol. 21 (2005) 962-970.

[2] S. Bayne. Dental Biomaterials: Where are we and where are we going? J of Dental Education, Vol. 69 (2005) 571-85.

[3] J.L. Ferracane. Developing a more complete undarstanding of stresses produced in dental 
composites during polymerisation. Dent Mater, Vol. 21 (2005) 36-42.

[4] A.J. Feilzer, A.J. De Gee, C.L. Davidson. Setting stress in composite resin in relation to configurationof the restoratives. J Dent Res, Vol. 66 (1987) 1636-72.

[5] H.Y. Chen, J. Manhart, R. Hickel, K.H. Kunzelmann. Polymerization contraction stress in light cured packable composite resin. Dent Mater, Vol. 17 (2001) 253-259.

[6] D.C. Wats, A.S. Marouf, A.M. Al-Hindi. Photo-polymerization shrinkage-stress kinetics in resin-composites:methods development. Dent Mater, Vol. 19 (2003) 1-11.

[7] R.L. Sakaguchi, B.D. Wiltbank, C.F. Murchison. Contraction force rate of polymer composites is linearly correlated with irradiance. Dent Mater, Vol 20 (2004) 402-407.

[8] Y. Kinomoto, M. Torii. Photoelastic analysis of polymerization contraction stresses in resin composite restorations. J Dent, Vol. 26 (1998) 16571.

[9] Y. Kinomoto, M. Torii, F. Takeshige, S. Ebisu. Comparison of polymerization contraction stresses between self- and light-curing composites. $\mathrm{J}$ Dent, Vol. 27 (1999) 383-389.

[10] Y. Kinomoto, M. Torii, F. Takeshige, S. Ebisu. Polymerization contraction stresses of resin based composite restorations within beveled cavity preparations of Class I restorations. Am J Dent, Vol 16 (2003) 139-143.

[11] P. Ausiello, A. Apicella, C.L. Davidson, S. Rengo. 3D finite element analyses of cusp movements in a human upper premolar restored with adhesive resin-based composites. J of Biomechanics, Vol 34 (2001) 1269-77.

[12] G.A. Laughlin, J.L. Williams, J.D. Eick. The influence of system compliance and sample geometry on composite polymerisation shrinkage stress. J Biomed Mater Res (Appl Biomater), Vol 63 (2002) 671-678.
[13] M.T. Manley, B. Ovryn, L.S. Stern. Evaluation of double-exposure holographic interferometry for biomechanical measurements in vitro. J Orthop Res, Vol 5 (1997) 144-9.

[14] A. Wesson, G.R. Goldstein, A. Schulman. Flexion characteristics of fixed partial denture frameworks tested by using elapsed-time holographic interferometry. J Prosthet Dent, Vol 60 (1988) 308-10.

[15] P.R. Wedendal, H.G. Bjelkhagen. Dental holographic interferometry in vivo utilizing a ruby laser system. I. Introduction and development of methods for precision measurements on the functional dynamics of human teeth and prosthodontic appliances. Acta Odont Scand, Vol 32 (1974) 131-145.

[16 ] Je Kasper, A.S. Feller. The complete book of holograms, how they work and how to make them. Mineola, New York Dover publications, Inc. 2001, 5-127.

[17] D. Pantelić, L. Blažić, S. Savić-Šević, B. Murić, D. Vasiljević, B. Panić, I. Belić. Real-time measurment of internal stress of dental tissue using holography. Optics Express, Vol 15 (2007) 68236830.

[18] K.S. Vandewalle, J.L. Ferracane, T.J. Hilton, R.L. Erickson, R.L. Sakaguchi. Effect of energy density on properties and marginal integrity of posterior resin composite restorations. Dent Mater. Vol 20 (2004) 96-106.

[19] S. Rosenstiel, M. Land, J. Fujimoto. Contemporary fixed prosthodontics. Mosby 2006.

[20] J.H. Kinney, S.J. Marshall, G.W. Marshall. The mechanical properties of human dentin: a critical review and re-evaluation of the dental literature. Crit Rev Oral Biol Med. Vol. 14 (2003) 13-29.

[21] L. G. Cunha, R. C. B. Alonso, C.S.C Pfeifer, L. Correr-Sobrinho, J.L. Ferracane, M. A. C. Sinhorereti. Contraction stress and physical properties development of resin- based composite irradiated using modulated curing methods at two C-factor levels. Dent Mater, Vol 24 (2008) 392-398.

\section{ХОЛОГРАФСКА ИНТЕРФЕРОМЕТРИЈА КАО МЕТОД ЗА МЕРЕЊЕ ДЕФОРМАЦИЈА НАСТАЛИХ КАО ПОСЛЕДИЦА ПОЛИМЕРИЗАЦИОНЕ КОНТРАКЦИЈЕ ДЕНТАЛНИХ КОМПОЗИТА}

Сажетак: Полимеризациона контракција једна је од најлошијих особина денталних композитних материјала на бази смола и она може имати негативан утицај на клинички успех терапије денталним композитима. Пошто је композит адхезивно везан, контракција композитног материјала, која се јавља у току полимеризације, доводи до појаве деформација и напона тврдих зубних ткива. Полимеризациона контракција такође утиче на остваривање везе између композитног материјала и тврдих зубних ткива. Циљ рада је презентовање холографске интерферометрије као методе за 
детекцију и мерење деформација тврдих зубних ткива, насталих као последица полимеризационе контракције денталног композита. Материјал и метод: деформације тврде зубне супстанце мерене су експериментално, холографском интерферометријом у реалном времену на зубима горње вилице. Величина деформације израчуната је на основу броја интерферометријских пруга које су се појавиле у току процеса полимеризације. Резултати: деформације су забележене на круничном делу зуба у распону

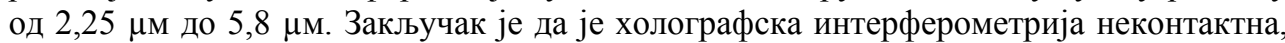
недеструктивна, веома прецизна методологија за мерење деформација тврдих зубних ткива које су настале као последица полимеризационе контракције денталног композита.

Кључне речи: композитни материјал на бази смола, полимеризациона контракција, холографска интерферометрија. 